\title{
Effect of Lead Graded Doses in Mactra Corallina Gills: Antioxidants Status, Cholinergic Function and Histopathological Studies
}

\author{
Imene Chetoui ${ }^{1,}$, , Safa Bejaoui ${ }^{1}$, Chaima Fouzai ${ }^{1}$, Wafa Trabelsi ${ }^{1}$, Salwa Nechi ${ }^{2}$, \\ Emna Chelbi ${ }^{2}$, Mohamed Ghalghaf ${ }^{3}$, M'hamed El Cafsi ${ }^{1}$, Nejla Soudani ${ }^{1}$ \\ ${ }^{1}$ Faculty of Sciences of Tunis, Biology Department, Laboratory of Ecology, Biology and Physiology of Aquatic Environment, University of \\ Tunis El Manar, Tunis, Tunisia \\ ${ }^{2}$ Anatomy and Cytology Service, Mohamed Taher Maamouri Hospital, Road Mrezka, Nabeul, Tunisia \\ ${ }^{3}$ Higher Institute of Fisheries and Aquaculture, Bizerte, Tunisia
}

Email address:

chetouiimene@gmail.com (I. Chetoui), safa.bejaoui@fst.utm.tn(S. Bejaoui), fouzai.chaima93@gmail.com (C. Fouzai), wafa.trabelsi@etudiant-fst.utm.tn(W. Trabelsi),Salwanechi@hotmail.com (S. Nechi), emnachelbi1@gmail.com (E.Chelbi), chalghafmed@yahoo.fr (M. Ghalghaf),mhamed.elcafsi@gmail.com (M. El Cafsi), nejla.soudani@tunet.tn (N. Soudani)

${ }^{*}$ Corresponding author

\section{To cite this article:}

Imene Chetoui, Safa Bejaoui, Chaima Fouzai, Wafa Trabelsi, Salwa Nechi, Emna Chelbi, Mohamed Ghalghaf, M'hamed El Cafsi, Nejla Soudani. Effect of Lead Graded Doses in Mactra Corallina Gills: Antioxidants Status, Cholinergic Function and Histopathological Studies. Journal of Chemical, Environmental and Biological Engineering. Vol. 5, No. 1, 2019, pp. 1-9. doi: 10.11648/j.jddmc.20190501.11

Received: March 12, 2019; Accepted: April 27, 2019; Published: June 12, 2019

\begin{abstract}
Lead is non-essential toxic metal used in the industrial process causes severe risk to aquatic organisms. This study aimed (aims) to evaluate the effect of $\mathrm{Pb}$ on oxidative stress in gills of Mactra corallina. During the experiment, bivalves were randomly divided into four groups, control served as control and D1, D2 and D3 groups were exposed to Pb graded doses $(1 \mathrm{mg} / \mathrm{L}, 2.5 \mathrm{mg} / \mathrm{L}$ and $5 \mathrm{mg} / \mathrm{L})$ during 5 days, respectively. $\mathrm{Pb}$ accumulation was significantly increased in all treated gills with doses dependent manner. The exposure of $\mathrm{M}$. corallina to $\mathrm{PbCl}_{2}$ promoted oxidative stress in gills with an increase in malondialdehyde (MDA) and in metallothionein (MTs) levels. Moreover, a decline in glutathione (GSH), non-protein-SH (NPSH) and ascorbic acid (Vit C) levels were detected in all treated groups. Thus, alterations of enzymatic antioxidants systems were confirmed by a significant increase of catalase (CAT) and decreases of glutathione peroxidase (GPx) and superoxide dismutase (SOD) activities in doses dependent manner. The cholinergic function was confirmed by a significant decrease of acetylcholinesterase (AChE) activity in the highest exposure dose. The impairment of the gill function was confirmed by the histological study.
\end{abstract}

Keywords: Gills, Histopathological Studies, Lead Exposure, Mactra Corallina, Oxidative Stress

\section{Introduction}

Aquatic systems are contaminated by different metals through inputs from human activities [1]. Lead $(\mathrm{Pb})$ is nonessential heavy metal, that can be provided from natural and industrials effluents including lead ore mining and smelting, refining, alkyl-lead petroleum combustion, batteries and cement manufacture [2]. In addition, $\mathrm{Pb}$ is among the most of inputs metals in water and sediment that could be accumulated by most aquatic taxa especially the faunal bivalves [3-4].

These taxa, such as Mactra corallina (M.corallina), are widely reported as bioindicators species in the monitoring applications, because of their filter feeders' mode, sedentary living and their capacity to accumulate trace elements [5-7]. The clam M.corallina, which generally distributed along Mediterranean and Atlantic coasts and estuaries, considered as an important sea food in Manches coast. In Tunisia, it has a large repartition from the Northern to Southern sandy beaches, occupying the lower infra-littoral zone (3to100 m depth). 
Nevertheless, there is a lack of information regarding the tolerance of gill $M$. corallina to $\mathrm{Pb}$ potential effects. The reason for appointing gills is because this tissue forms an active site for metal uptake and oxy-radical generation in addition to enzyme biotransformation process. One of the most important established mechanisms of $\mathrm{Pb}$ toxicity is this capacity to boosts the ROS production, which in turn results in cell membrane damage, protein oxidation and DNA alteration [8-12].

In this study gill of $M$. corallina was examined to evaluate the effect of $\mathrm{PbCl}_{2}$ graded doses exposure using biochemical parameters: lipid peroxidation, oxidative stress and histopathological changes.

\section{Materials and Methods}

\subsection{Chemicals}

Reduced glutathione (GSH), 5,5-dithio-bis-(2nitrobenzoicacid) (DTNB), 2-thiobarbituric acid) (TBA) were purchased from Sigma chemical Co (Saint Louis, MO63103, USA). All other chemicals were purchased from standard commercials suppliers.

\subsection{Experimental Exposure of Mactra Corallina}

$M$. corallina (average shell length: $3.5 \pm 0.63 \mathrm{~cm}$ and weight $8.03 \pm 0.47 \mathrm{~g}$ ) were sampled from Bizerte lagoon in depths greater than $1 \mathrm{~m}$ with scuba divers. Clams allowed acclimated for one week in twenty-liter aquaria renewed daily with fresh sea water. Control conditions systems were maintained: Temperature $\left(18^{\circ} \mathrm{C}\right)$, Salinity $(30 \mathrm{psu}), \mathrm{pH}$ (7.4 \pm 0.2$)$ and photo period (12/12). However, no type of food was attributed to $M$. corallina during the acclimatization and the experiment period. After acclimation, groups of individuals were transferred in $8 \mathrm{~L}$ plastic aquaria and control was enclosed, therefore, exposed to unmixed $\mathrm{PbCl}_{2}$ metal (Lead chloride; $\mathrm{PbCl}_{2}$; Sigma-Aldrich; powder 98\%) which was dissolved in pure water. The experiment was maintained for a period of 5 days under graduated $\mathrm{PbCl}_{2}$ concentrations as following: CT: control; D1: $1 \mathrm{mg} / \mathrm{L}$; D2: $2.5 \mathrm{mg} / \mathrm{L}$ and D3: $5 \mathrm{mg} / \mathrm{L}$ with controlled conditions as mentioned above. Each treatment was performed with three replicates exposure (25 bivalves per condition). The selected $\mathrm{Pb}$ concentration in our experiment was based on preliminary trials focused on other bivalves [13, 14]. No mortality was recorded during the experimental period.

\subsection{Samples Preparation}

In this study, gills of fifty clams were pooled and 9 replicates were used for each experimental group. Samples were homogenized in Tris- $\mathrm{HCl}$ buffer $(20 \mathrm{mM}$; $\mathrm{pH}=7.4)$ at cold, then, centrifuged at $10.000 \times \mathrm{g}$ for $20 \mathrm{~min}\left(4^{\circ} \mathrm{C}\right)$. Gills supernatants were stored in eppendorf tube sat $-80^{\circ} \mathrm{C}$ for oxidative stress analysis. Other portions were fixed in ethanol $\left(70^{\circ}\right)$ and embalmed in paraffin until histological analysis.

\subsection{Determination of Pb Content in Gills of M.corallina}

Gills of M.corallina were processed for $\mathrm{Pb}$ estimation according to the method described by Cheung and Wong [15]. Samples mineralization were obtained after addition of nitric acid $\left(\mathrm{NHO}_{3}\right)$ and hydrogen peroxide $\left(\mathrm{H}_{2} \mathrm{O}_{2} ; 37 \%\right)$ at a hot temperature. The mineralized solution was gauged with distillate water at $50 \mathrm{ml}$ until analysis. Metal content was determined by inductively coupled plasma mass spectrometry (ICP-MS) equipped with a graphite furnace. Blank samples and reference standard materials were processed to assure quality control.

\subsection{Biochemical Analyses}

\subsubsection{Protein Quantification}

Protein content was estimated according to Lowry et al., [16] method; using Folin Reagent and Bovine serum albumin (BSA) as a standard range.

\subsubsection{Malondialdehyde (MDA) Levels}

MDA level was determined according to Draper and Hadley (1990) [17] by spectrophotometer method at $532 \mathrm{~nm}$. An aliquot of $0.5 \mathrm{ml}$ was incubated in heated water $\left(37^{\circ} \mathrm{C}\right)$ for 1hour, then, mixed with $0.5 \mathrm{ml}$ of trichloroacetic acid (TCA $30 \%$ ). After centrifugation at $3500 \times \mathrm{g}$ for $10 \mathrm{~min}$ in cold $4^{\circ} \mathrm{C}$; $0.5 \mathrm{ml}$ of thiobarbituric acid (TBA $0.67 \%$ ) was added to $0.5 \mathrm{ml}$ of supernatant. There action was activated under heated incubation during $10 \mathrm{~min}$. Results were expressed as $\mathrm{nmol} / \mathrm{mg}$ protein.

\subsubsection{Glutathione (GSH) Levels}

GSH level was measured according to Ellman [18] at 412 $\mathrm{nm}$ after addition of 5-dithio-bis (2-nitrobenzoicacid) (DTNB). The concentration of GSH was calculated through a standard concentration and expressed as $\mu \mathrm{g} / \mathrm{mg}$ protein.

\subsubsection{Non protein-SH (NPSH) Levels}

NPSH levels were determined by the method of Ellman [18]. An aliquot of 100ųl was mixed with trichloroacetic acid (10\%). After centrifugation for $10 \mathrm{~min}, \mathrm{SH}$ groups were determined in a pure supernatant under addition of potassium phosphate buffer $(\mathrm{pH}=7.4 ; 1 \mathrm{M})$ and DTNB $(10 \mathrm{mM})$. The absorbance of colorimetric reaction was measured at $412 \mathrm{~nm}$ and NPSH level was expressed as $\mu \mathrm{mol} / \mathrm{mg}$ protein.

\subsubsection{Ascorbic Acid (Vit C) Levels}

Vit $\mathrm{C}$ level was measured in gills and tissues according to Jaques Silva et al [19]. Protein was precipitated in cold trichloracetic acid solution and centrifuged during 10 minutes. Then, the supernatant was incubating in hot temperature $\left(85^{\circ} \mathrm{C}\right)$ during 30 minutes with dinitrophénylhydrazine $(\mathrm{DNPH})$ and copper sulfate $(\mathrm{CuSo} 4)$. There action product was determined after addition of sulfuric acid (65\%). Dates' were expressed as $\mu \mathrm{g}$ of ascorbic acid per mg of protein.

\subsubsection{Superoxide Dismutase (SOD) Activity}

SOD activity was analyzed according to the method described by Beauchamp and Fridovich [20]. There action mixture contained: $50 \mu \mathrm{l}$ of tissue homogenates in $20 \mathrm{mM}$ Tris- $\mathrm{HCl}$ buffer $(\mathrm{pH}=7.4), \quad 0.1 \mathrm{mM} \quad$ EDTA, $13 \mathrm{mM} \quad$ l- 
methionine, $2 \mathrm{mM}$ riboflavin and $75 \mathrm{mM}$ Nitro blue Tetrazolium (NBT). The developed blue color was measured at $560 \mathrm{~nm}$ after incubation under light. Data were expressed as $\mu \mathrm{mol} / \mathrm{mg}$ protein.

\subsubsection{Glutathione Peroxidase (GPx) Activity}

Using Flohea nd Gunzler [21] procedure, glutathione peroxidase activity (GPx) was measured spectrophotometrically at 340. GPx was expressed as nmol of GSH oxidized $/ \mathrm{min} / \mathrm{mg}$ protein.

\subsubsection{Catalase (CAT) Activity}

CAT activity was determined by the method of Aebi [22] using $\mathrm{H}_{2} \mathrm{O}_{2}(0.5 \mathrm{M})$ as a substrate. The concentration of $\mathrm{H}_{2} \mathrm{O}_{2}$ was determined every 15 seconds after initiation of the reaction by the addition of samples. One unit of CAT was defined as $\mu$ mole $\mathrm{H}_{2} \mathrm{O}_{2}$ consumed $/ \mathrm{min} / \mathrm{mg}$ of protein.

\subsubsection{Metallothionein (MTs) Levels}

MTs were determined according to the method developed by Viarengo et al., [23] modified by Petrovic et al., [24]. An aliquot of supernatant $(500 \mu \mathrm{l})$ was added to ethanol/chloroform solution $(95 \% ; 1 \%)$ and centrifuged during $10 \mathrm{~min}$ in cold for $6000 \mathrm{~g}$. The obtained pellets were suspended in $\mathrm{NaCl}(0.25 \mathrm{M})$ and EDTA $(1 \mathrm{mM})$. MTs reaction was detected under DTNB at 412nm. Results were expressed as nmol $\mathrm{GSH} / \mathrm{mg}$ protein.

\subsubsection{Acetylcholinesterase (AChE) Activity}

AChE activity was measured using the colorimetric method of Ellman et al., [25]. Acetylthiocholine iodide was used as a substrate, in a concentration of $8.25 \mathrm{mM}$. The kinetics of AChE was measured spectrophotometrically at $412 \mathrm{~nm}$ and determined during $5 \mathrm{~min}$ each 60 seconds. AChE activity was expressed as nmol of substrate $/ \mathrm{min} / \mathrm{mg}$ protein

\subsection{Histological Analysis}

Histology of gills was examined using a technique of Martoja and Martoja-Pierson [26]. Sections of the gills were fixed for $48 \mathrm{~h}$ in buffered formalin $(10 \%)$, then transferred into $70 \%$ ethanol. Sections of $6-\mathrm{mm}$ thickness were cut mounted on glass slides and stained with a solution of hematoxylin and eosin according to routine histological techniques. Each histological section was examined in detail under microscopic analysis coupled with CCD camera.

\subsection{Statistical Analysis}

Results are expressed as means \pm SE (standard error) for each analysis. The level of significance was as curtained at 0.05. Differences in antioxidants biomarkers between control and the exposure concentrations were assessed by one-way ANOVA. The mean variance in the data set was detected using principal component analysis (PCA). A Pearson correlation matrix between biochemical parameters and $\mathrm{Pb}$ contents in gills of M.corallina was established.

\section{Results}

\subsection{Pb content in M. Corallina Gills}

Significant increases of $\mathrm{Pb}$ contents were observed in all treated M.corallina gills $(\mathrm{p}<0.001)$ as compared to the control. $\mathrm{Pb}$ content varied between $0.22 \pm 0.010 \mathrm{mg} / \mathrm{kg} \mathrm{DW}$ and $1.45 \pm 0.09 \mathrm{mg} / \mathrm{kg} \mathrm{DW}$ in control and D3 $\left(5 \mathrm{mg} / \mathrm{LPbCl}_{2}\right)$ groups (Figure1). After exposure to graded dose $\left(5 \mathrm{mg} / \mathrm{LPbCl}_{2}\right), \mathrm{Pb}$ was accumulated in gills more than the authorized limit for human consumption (Figure1).

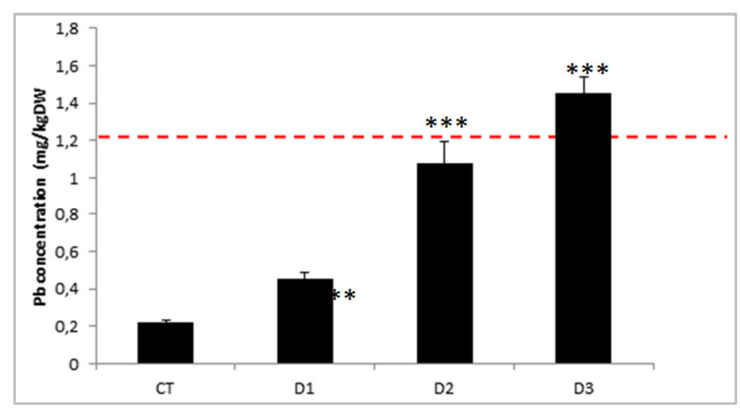

Figure 1. Concentration of $\mathrm{Pb}$ in control and treated M.corallina gills with $\mathrm{PbCl}_{2}$ graded doses (D1, D2, D3) after 5 days of treatment.

The standard limit was presented by line obtained from SRM 2976 (muscle tissue, National institute of standards and technology). Values are expressed as means $\pm \mathrm{SD}(\mathrm{n}=6) \mathrm{D} 1: 1 \mathrm{mg} / \mathrm{LPbCl}_{2} ; \mathrm{D} 2: 2.5 \mathrm{mg} / \mathrm{LPbCl}_{2} ; \mathrm{D} 3: 5 \mathrm{mg} / \mathrm{LPbCl}_{2}$ $\mathrm{PbCl}_{2}$ groups VS controls: $* * * \mathrm{P}<0.001$

\subsection{Malondialdehyde (MDA) Levels in M. Corallina Gills}

Our results revealed significant increases of MDA levels $(+48 \%,+32 \%,+81 \%$ respectively) in the gills of all treated groups when compared to controls (Table1). This peroxidation was confirmed by a positive correlation with MDA levels and $\mathrm{Pb}$ contents in all exposed gills (Table 2)

\subsection{Non Enzymatic Antioxidants Levels in M Corallina Gills}

Results showed significant decreases in GSH (-15 and-19\%), NPSH (-26 and -34\%) and Vit C (-35 and-63\%) levels in treated gills $M$. corallina with 1 and $2.5 \mathrm{mg} / \mathrm{L}$ of $\mathrm{PbCl}_{2}$ respectively when compared to the control (Table 1).

These non enzymatic antioxidants activities seem to be correlated $(\mathrm{p}<0.05)$ positively with lipid peroxidation index (Table 2).

\subsection{Enzymatic Antioxidants Activities in M.Corallina Gills}

The enzymatic antioxidants activities (CAT, GPx and SOD) in control and treated bivalves are illustrated in Table1. Treated gills at different $\mathrm{Pb}$ concentrations showed a significant decrease in their SOD $(-24,-30,-16 \%)$ and GPx activities (-33,-42 and$21 \%$ ) at $1,2.5$ and $5 \mathrm{mg} / \mathrm{LPbCL}_{2}$ respectively. However, CAT activity demonstrated an increase $(+95,+186$ and $+98 \%$, respectively) in the treated gills with graded doses 1, 2.5 and $5 \mathrm{mg} / \mathrm{LPbCl}_{2}$ (Table 1 ).

The activity of CAT in gills was negatively correlated with SOD and GPx activities whereas it presents a positive correlation with AChE activity (Table 2). 
Table 1. MDA, non-enzymatic levels (GSH, NPSH and Vit C levels) and enzymatic activities (CAT, GPx, SOD) in control and treated M.corallina gills with $\mathrm{PbCl}_{2}$ graded doses $(D 1, D 2, D 3)$ after 5 days of treatment.

\begin{tabular}{lllll}
\hline Parameters and treatments & CT & D1 & D2 & D3 \\
\hline $\mathrm{MDA}^{\mathrm{a}}$ & $1.51 \pm 0.27$ & $2.23 \pm 0.08^{* * *}$ & $2 \pm 0.09^{* * *}$ & $2.74 \pm 0.14^{* * *}$ \\
$\mathrm{GSH}^{\mathrm{b}}$ & $3.50 \pm 0.52$ & $2.67 \pm 0.25^{* *}$ & $2.19 \pm 0.33^{* *}$ & $2.98 \pm 0.4^{*}$ \\
$\mathrm{NPSH}^{\mathrm{c}}$ & $0.16 \pm 0.02$ & $0.12 \pm 0.01^{* * *}$ & $0.11 \pm 0.01^{* * *}$ & $0.13 \pm 0.01^{* * *}$ \\
$\mathrm{VitC}^{\mathrm{a}}$ & $18.91 \pm 4.23$ & $12.23 \pm 1.30^{* * *}$ & $7.35 \pm 1.92^{* * *}$ & $15.05 \pm 2.54^{* * *}$ \\
$\mathrm{CAT}^{\mathrm{d}}$ & $5.50 \pm 1.85$ & $10.75 \pm 1.34^{* * *}$ & $15.75 \pm 2.68^{* * *}$ & $10.89 \pm 1.55^{* * *}$ \\
$\mathrm{GPx}^{\mathrm{e}}$ & $11.52 \pm 1.26$ & $7.63 \pm 0.88^{* * *}$ & $6.66 \pm 0.61^{* * *}$ & $9.02 \pm 0.72^{* * *}$ \\
$\mathrm{SOD}^{\mathrm{f}}$ & $19.69 \pm 2.04$ & $14.75 \pm 0.19^{* * *}$ & $13.63 \pm 1.40^{* * *}$ & $16.49 \pm 1.60^{* * *}$ \\
\hline
\end{tabular}

Values are expressed as means $\pm \mathrm{SD}(\mathrm{n}=9)$.

$\mathrm{D} 1: 1 \mathrm{mg} / \mathrm{LPbCl}_{2} ; \mathrm{D} 2: 2.5 \mathrm{mg} / \mathrm{LPbCl} ; \mathrm{D} 3: 5 \mathrm{mg} / \mathrm{LPbCl}_{2}$

a: $\mathrm{nmol} / \mathrm{mg}$ protein

b: $\mu \mathrm{g} / \mathrm{mg}$ protein.

c: $\mu \mathrm{mol} / \mathrm{mg}$ protein.

$\mathrm{d}: \mu \mathrm{mol} \mathrm{H}_{2} \mathrm{O}_{2}$ consumed $/ \mathrm{min} / \mathrm{mg}$ protein.

e: $\mathrm{nmolesGSH} / \mathrm{min} / \mathrm{mg}$ protein.

f: $\mathrm{U} / \mathrm{mg}$ protein.

$\mathrm{PbCl}_{2}$ groups VS controls: **P<0.01; *** $\mathrm{P}<0.001$.

\subsection{Metallothionein Levels (MTs) in M.Corallina Gills}

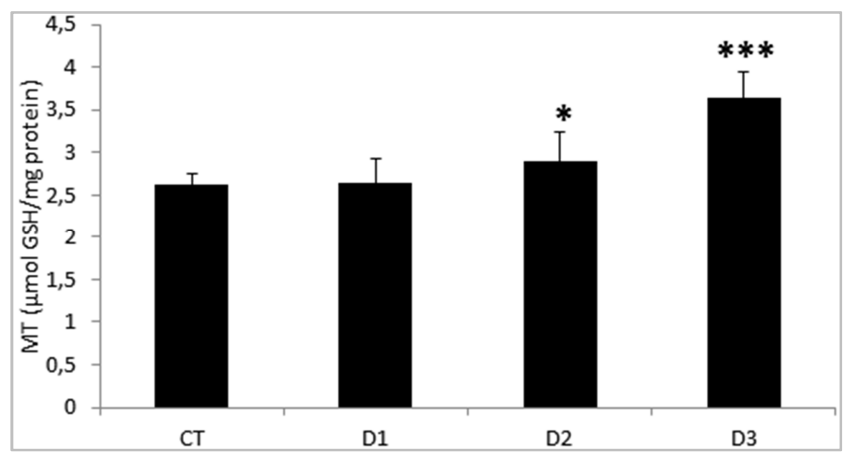

Figure 2. MTs levels in control and treated M.corallina gills with $\mathrm{PbCl}_{2}$ graded doses $(D 1, D 2, D 3)$ after 5 days of treatment. Values are expressed as means $\pm S D(n=9)$.

$\mathrm{D} 1: 1 \mathrm{mg} / \mathrm{LPbCl}_{2} ; \mathrm{D} 2: 2.5 \mathrm{mg} / \mathrm{LPbCl}_{2} ; \mathrm{D} 3: 5 \mathrm{mg} / \mathrm{LPbCl}_{2}$. $\mathrm{PbCl}_{2}$ groups VS controls: $* \mathrm{P}<0.05, * * * \mathrm{P}<0.001$.

A significant increase of MTs level was observed in treated M.corallina with 2.5 and $5 \mathrm{mg} / \mathrm{L}$ of $\mathrm{PbCl}_{2}$ by +55 and $+88 \%$. While, no significant change was noted in the first treatment $\left(1 \mathrm{mg} / \mathrm{L}\right.$ of $\left.\mathrm{PbCl}_{2}\right)$ than the controls (Figure 2). An important positive correlation between MTs and $\mathrm{Pb}$ contents and MDA levels was observed in our study. However, any significant correlation is recorded between metallothionein and antioxidants activities such as enzymatic and nonenzymatic (Table 2).

\subsection{Acetylcholinesterase Activity}

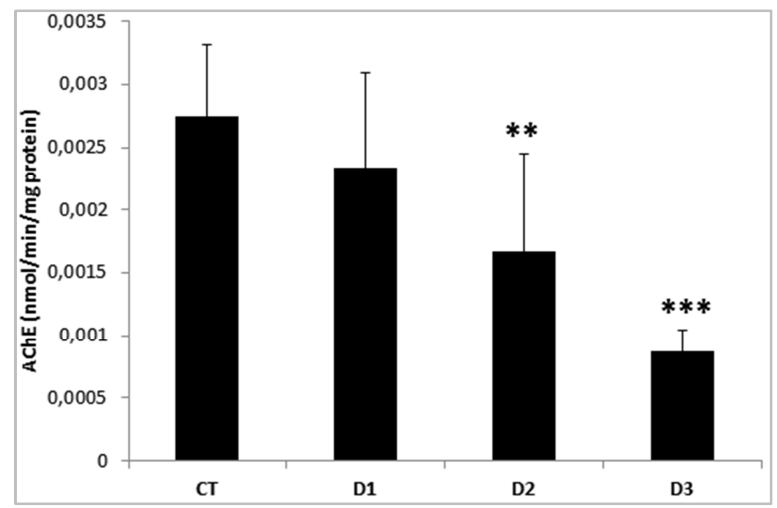

Figure 3. AChE activity in control and treated M. coralline gills with $\mathrm{PbCl}_{2}$ graded doses (D1, D2, D3) after 5 days of treatment.

Values are expressed as means $\pm \mathrm{SD}(\mathrm{n}=9)$.

$\mathrm{D} 1: 1 \mathrm{mg} / \mathrm{LPbCl}_{2} ; \mathrm{D} 2: 2.5 \mathrm{mg} / \mathrm{LPbCl}_{2} ; \mathrm{D} 3: 5 \mathrm{mg} / \mathrm{LPbCl}_{2}$

$\mathrm{PbCl}_{2}$ groups VS controls: $* * \mathrm{P}<0.01,{ }^{* * *} \mathrm{P}<0.001$.

Our results revealed a significant decrease of AChE activity in the gills of all treated group at graded doses (-15, 40 and $-70 \%$, respectively) when compared to those of controls (Figure 3).

A great negative correlationis observed between the AChE activity and nonenzymatic antioxidant systems (Table 2).

Table 2. Correlation analysis (Pearson correlation) between Pb contents and biochemical parameters (MDA, GSH, NPSH, VitC, CAT, GPx, SOD, MT and $A C h E)$ in control and treated M. coralline gills with $\mathrm{PbCl}_{2}$ graded doses (D1, D2, D3) after 5 days of treatment.

\begin{tabular}{|c|c|c|c|c|c|c|c|c|c|c|}
\hline Parameters & Pb contents & Protein & MDA & MT & NPSH & GSH & VitC & CAT & SOD & GPx \\
\hline Protein & 0.46 & & & & & & & & & \\
\hline MDA & $0.60^{*}$ & 0.09 & & & & & & & & \\
\hline MT & $0.78^{*}$ & -0.08 & 0.51 & & & & & & & \\
\hline NPSH & -0.50 & $-0.96^{*}$ & $0.66^{*}$ & -0.03 & & & & & & \\
\hline GSH & -0.38 & $-0.90^{*}$ & $0.61^{*}$ & 0.04 & $0.92^{*}$ & & & & & \\
\hline VitC & -0.32 & $-0.81^{*}$ & $0.84^{*}$ & 0.22 & $0.76^{*}$ & $0.71^{*}$ & & & & \\
\hline CAT & $0.60^{*}$ & $0.70^{*}$ & -0.50 & 0.24 & $-0.74^{*}$ & $-0.66^{*}$ & $-0.66^{*}$ & & & \\
\hline SOD & -0.36 & $-0.96^{*}$ & $0.65^{*}$ & 0.15 & $0.93^{*}$ & $0.90^{*}$ & $0.79^{*}$ & $-0.65^{*}$ & & \\
\hline
\end{tabular}




\begin{tabular}{lllllllllll}
\hline Parameters & Pb contents & Protein & MDA & MT & NPSH & GSH & VitC & CAT & SOD & GPx \\
\hline GPx & -0.51 & $-0.89^{*}$ & 0.55 & 0.02 & $0.87^{*}$ & $0.83^{*}$ & $0.72^{*}$ & $-0.71^{*}$ & $0.87^{*}$ & \\
AChE & 0.46 & $1.00^{*}$ & $-0.73^{*}$ & -0.08 & $-0.96^{*}$ & $-0.90^{*}$ & $-0.81^{*}$ & $0.70^{*}$ & $-0.96^{*}$ & $-0.89^{*}$ \\
\hline
\end{tabular}

*Correlation coefficients statistically significant $(\mathrm{p}<0.05)$.

\subsection{Histological Analysis}

Control and treated gill structures are shown in Figure 4. Gills of all experimental conditions were characterized by frontal, intermediate, abfrontal zones with ciliary discs, haemolymphatic sinus and connective tissues (Figure 4C).

Exposure to $\mathrm{PbCl}_{2}$ induced degenerative changes in the gill
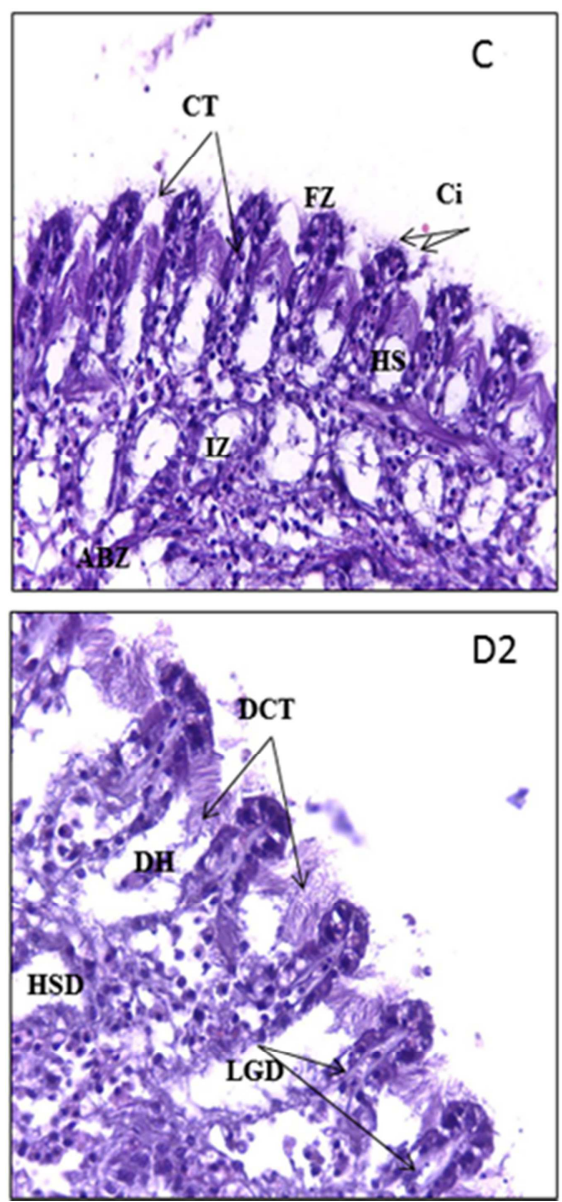

organ. $\mathrm{PbCl}_{2}$ exposure causes dilatation of haemolymphatic sinus and cilia degradation (Figure $4 \mathrm{D} 1$ ).

The vacuolization, lipofuscion granules degradation and disorganization of the intermediate and frontal zones were also observed (Figure 4 D2. D3). The most effects were more evident at the sharpest exposure dose $(5 \mathrm{mg} / \mathrm{L})$.
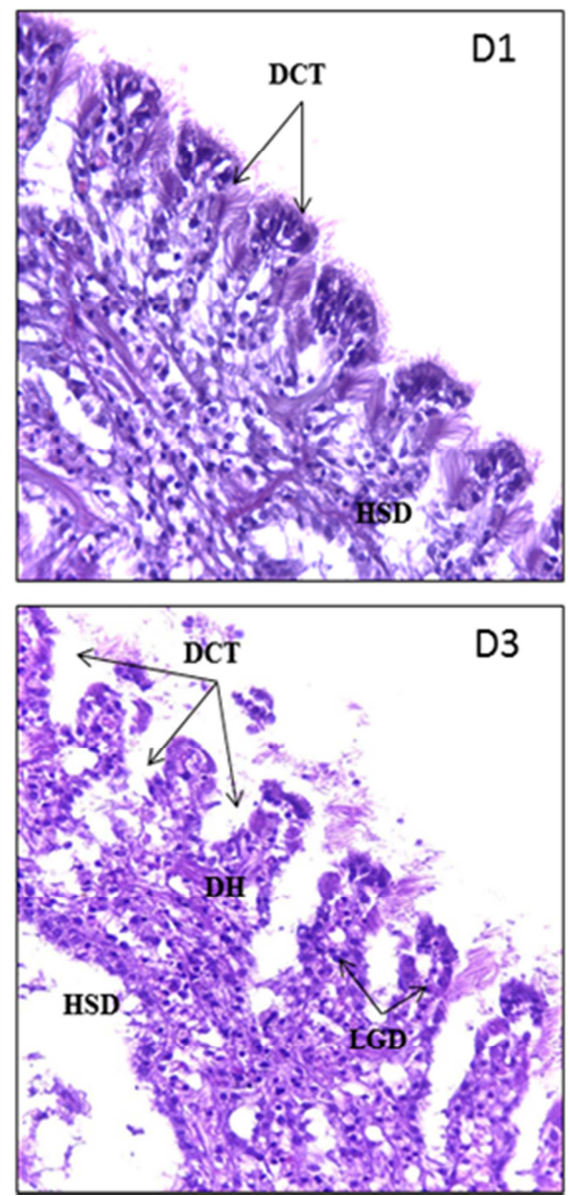

Figure 4. Histological structure of treated (D1,D2 and D3) and control (C) gills exposed to PbCl2 graded doses during 5 days. CT: connective tissue, FZ: frontal zone, IZ: Intermediate zone, ABZ: abfrontal zone, HS: hemolymphatic sinus, Ci: cillia, DCi: deterioration of cilia, DH: dilatation of hemolymphatic sinus, DCT: degradation of the connective tissue, HSD: haemolymphatic sinus degradation, LGD: lipofuscion granules degradation.

\subsection{Principal Component Analysis (PCA)}

The principal component analysis (PCA) was performed to understand the response of biomarkers after lead exposure in Mactra corallina gills. Results were shown in Fig (5 A, B), allowed us to retain the first two factorial axes that explain $87.94 \%$ of the total variance. Factorldisplayed $69.10 \%$ of the total variance, defined by NPSH, GSH, Vit C levels and SOD, GPx and AChE activities (Figure 4A). Whereas, Factor $2(18.83 \%)$ was characterized by a higher concentration of $\mathrm{Pb}$ and MTs levels. Only CAT activity and MDA levels were considered as intermediates compounds for the two axes.

PCA results showed that there was a significant separation between control and the other groups (Fig.5B). Control gills were projected in the positive side of first and negative second factorials axes, explaining by the high levels of antioxidants systems which were decreased in all treated groups. The second group was constituted by clams from D1 and D2 which were projected in the negative side of two factorials axis; showing an intermediate and closer defense state. The third one including $\mathrm{M}$. coralline from D3 correlated by the most tested parameters such as $\mathrm{Pb}$ concentration, MTs levels. Clearly, the biomarkers response involved in oxidative stress were significantly increased in elevated $\mathrm{PbCl}_{2}$ treatment groups as compared to control and D1 ones. 

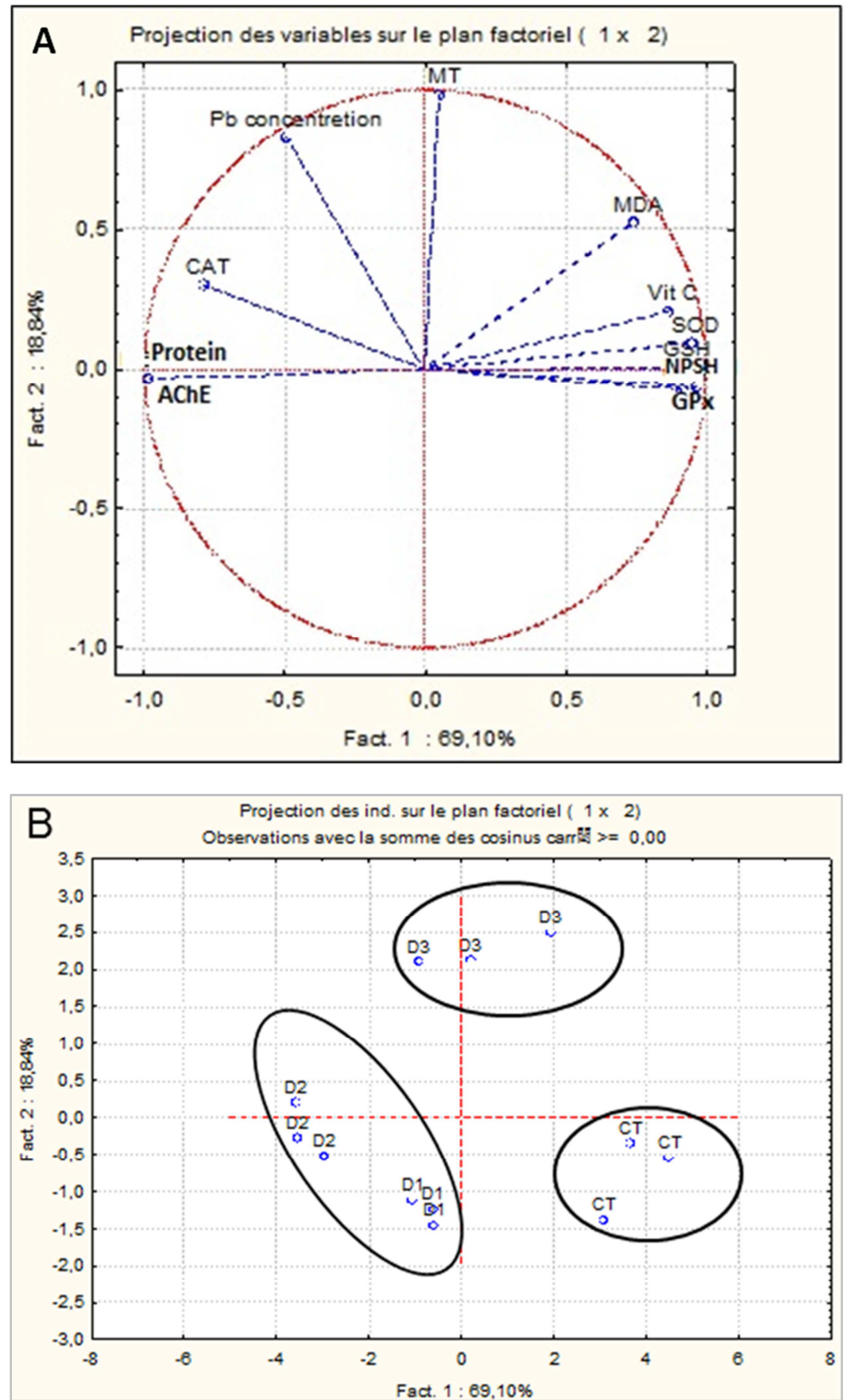

Figure 5. Principal analysis component (PCA) represented by two factors $F 1$ and F2 and produced by biochemical variables in control and treated M. corallina gills with $\mathrm{PbCl}_{2}$ graded doses (D1, D2, D3) after 5 days of treatment: (A) Projection of the variables on the factor-plane $(1 \times 2)$, (B) Projection of the cases on the factor-plane $(1 \times 2)$.

$\mathrm{D} 1,1 \mathrm{mg} / \mathrm{LPbCl}_{2} ; \mathrm{D} 2,2.5 \mathrm{mg} / \mathrm{LPCl}_{2} ; \mathrm{D} 3,5 \mathrm{mg} / \mathrm{LPbCl}_{2}$.

\section{Discussion}

Exposure to $\mathrm{PbCl}_{2}$ for 5 days was sufficient to induce changes in gills metabolism. Our experimental study showed a significant accumulation of $\mathrm{Pb}$ levels with dose dependent manner. Important accumulation of $\mathrm{Pb}$ in gills was probably an indication of the ability of bivalves to lead accumulation. Thus, the change in accumulation pattern observed could associate to $\mathrm{Pb}$ graded doses exposure, since gills are considered as the first contact with the metal exposure that has a large surface area of the thin epithelium [27].

Previous research has demonstrated that exposure to $\mathrm{Pb}$ can induce free radical generation in the cell [28]. Due to the disturbance of pro-oxidants and oxidants systems, several injuries could be observed in macromolecules structures. The overproduction of ROS may cause lipid damage via reacting 
with the double bonds of membrane lipids (such as PUFA), ultimately resulting in the appearance of toxic substances [29]. MDA is considered as a marker of lipid oxidation widely used in the in vivo and in vitro assessment [30-31].

In the current study, MDA was prominently increases in gills of all exposed groups compared to control. A significant and positive correlation was determined between MDA and $\mathrm{Pb}$ content in the gill tissue. This can lead to a rise in ROS production in lipid membrane which reacts with the double bonds of PUFA causing their peroxidation. Our results were in accordance with the study of Shenai-Tirodkar et al., [4], reporting the rise of gills MDA levels after exposure of oysters to $\mathrm{Pb}$.

It's known that cellular damages induced by metals are the result of ROS overproduction and the compensatory response from endogenous and antioxidants such as enzymatic and nonenzymatic systems [8]. Among them, superoxide dismutase (SOD) is a catalyzer compound that converts superoxide radicals to hydrogen peroxide which was transformed in to $\mathrm{H}_{2} \mathrm{O}$ via glutathione peroxidase $(\mathrm{GPx})$ and catalase (CAT) [32]. In all $\mathrm{PbCl}_{2}$ treated gills, the decrease of GPx and SOD activities were observed as compared to the control. This depletion indicates the probable dysfunction of those antioxidants by ROS or it' sever utilization to overcome with $\mathrm{Pb}$ toxicity. Nonetheless, CAT activity was increased in all groups demonstrated the protective action of this enzyme against ROS to reduce $\mathrm{Pb}$ toxicity. Thus, the activation of this enzyme was probably linked to $\mathrm{Pb}$ accumulation that shows an important correlation between its contents and enzymes responses in gills. In fact, this induction may be a compensatory adaptive mechanism to prevent the generation of highly toxic $\mathrm{OH}$ radicals via neutralization of $\mathrm{H}_{2} \mathrm{O}_{2}$ overproduction [33]. Several experimental investigations have demonstrated that $\mathrm{Pb}$ disturbs antioxidants enzymes activities [34].

Likewise, change in membrane permeability including MDA induction was related to the alterations of nonenzymatic antioxidants status by allowing faster ROS intake [35]. In our study, significant increases in GSH, NPSH and Vit $\mathrm{C}$ levels in all treated bivalves were positively correlated with lipid peroxidation (MDA levels). Such increases demonstrate the neutralize function of these enzymes against $\mathrm{Pb}$ toxicity, inducing an excessive generation of radicals as reported previously by Coelho et al., [36] after exposure of Scrobicularia plana to mercury.

As a protein of metal-binding MTs are involved in the detoxification and the accumulation of several pollutants such as metals [37] and protect the cell against the cytotoxic effects of ROS production [38]. Hence, it is widely suggested as a bioindicator in the bio-monitoring programs to asses' metals contaminations. Our results demonstrated an increase with dose dependent manner in MTs levels after exposure to gradual $\mathrm{PbCl}_{2}$ doses. This increase was affirmed by a significant and positive correlation with $\mathrm{Pb}$ contents in gills of M. coralline that could possibly be explained by an adaptive response against its accumulation. These results were similar to the findings of Chalkiadaki et al,. [13] where the authors found an effective increase in the MTs levels in gills of Mytilus galloprovincialis after 20 days of exposure to $\mathrm{Pb}$.

Acetylcholinesterase (AChE) activity was comm. only used as a biomarker of neurotoxicity (...). In our current study, the ROS production and the successive oxidative stress induced by $\mathrm{PbCl}_{2}$ resolved the changes in the gills of $\mathrm{PbCl}_{2}$ treated M. coralline established by a significant inhibition of AChE activity. This decrease could be associated with the deactivation of ChEs by metals that binding to their anionic site [39]. In other hands, the decline of AChE activity was highly correlated with the nonenzymatic antioxidant systems in our experiment. We can suggest that the inhibition of AChE activity under the effect to lead is might be caused by binding of metals to the functional groups of proteins like imidazole, sulfhydryl and carboxyl [40]. Similar to our result, Dafre et al. [41] have shown that exposure to $\mathrm{Pb}$ causes a marked reduction in AChE activity in Perna perna.

According to the histological study, the gills were extensively damaged with cilia degradation, dilatation of haemolymphatic sinus, lipofuscion granules degradation and disorganization of the intermediate and frontal zones. The vacuolization was also observed which was related to the rise of lipid peroxidation which caused membrane damages in the gills.

\section{Conclusion}

Based on the results of the investigated biochemical markers and histological study, we may conclude that oxidative stress generated in gills of $\mathrm{M}$. coralline especially dependent on the concentration of $\mathrm{Pb}$ exposure. A decrease in SOD, GPx activities, and GSH, NPSH, Vit C levels which associated with an increase in MDA level in treated groups especially under sharpest dose. This biochemical modification corresponded to histological.

\section{Acknowledgements}

This study was supported by Tunis University of Sciences and the Laboratory of Ecology, Biology and Physiology of Aquatic organisms.

\section{Conflict of Interest}

The authors declare that they have no conflict of interest.

\section{References}

[1] J. A. Campillo, M. N. Albentosa, J. Valdes, R. MorenoGonzalez, and V. M. Leon, "Impact assessment of agricultural inputs into a Mediterranean coastal lagoon (Mar Menor, SE Spain) on transplanted clams (Ruditapes decussatus) by biochemical and physiological responses, "Aqua. Toxicol, Vol. 142, pp. 365-379, 2013.

[2] M. Dellali, M. Romeo, M. Gnassia-Barelli, and P. Aissa, "A multivariate data analysis of the clam Ruditapes decussatus as sentinel organism of the Bizert a lagoon (Tunisia)," Water. Air. Soil. Pollut, Vol. 156, pp. 131-144, 2004. 
[3] S. Mombo, C. Dumat, M. Shahid, and et al, "Socioscientific analysis of the environmental and health benefits as well as potential risks of cassava production and consumption," Environ. Sci. Pollut. R, Vol. 24, pp. 5207$5221,2016$.

[4] P. Shenai Tirodkar, MU. Gauns, MWA, Mujawar, and et al, "Antioxidant responses in gills and digestive gland of oyster Crassostrea madrasensis (Preston) under lead exposure.," Ecotoxicol. Environ. Saf, Vol. 142, pp. 87-94, 2017.

[5] Y. De Lafontaine, F. Gagné, C. Blaise, G. Costan, P. Gagnon, and H. M. Chan, "Biomarkers in zebra mussels (Dreissena polymorpha) for the assessment and monitoring of water quality of the St Lawrence River (Canada)," Aqua. Toxicol, Vol. 50, pp. 51-71, 2000.

[6] MH. S. Kraak, Y. A. Wink, C. S. Stuijfzand, M. C. BuckertdeJong, C. J. de Groot, and W. Admiraal "Chronic ecotoxicity of $\mathrm{Zn}$ and $\mathrm{Pb}$ to the zebra mussel Dreissena polymorpha, "Aqua. Toxicol, Vol. 30, pp. 77-89, 1994.

[7] D. Rittschof, and P. McClellan-Green, "Molluscs as multi disciplinary models in environment toxicology, "Mar. Pollut. Bull, Vol. 50, pp. 369-373, 2005.

[8] B. Halliwell, and J. M. C. Gutteridge, "Detection of free radicals and other reactive species: trapping and fingerprinting," In: Free. Radic. Biol. Med, B. Halliwell, and J. M. C. Gutteridge, Eds. Oxford: University Press, 2001, pp. 351-425.

[9] H. Gurer, and N. Ercal, "Can antioxidants be beneficial in the treatment of lead poisoning?" Free. Radic. Biol. Med, Vol. 29 (10), pp. 927-945, 2000.

[10] N. Ercal, H. Gurer-Orhan, and N. Aykin-Burns, "Toxic metals and oxidative stress part I: mechanisms involved in metal induced oxidative damage, "Curr. Top. Med. Chem, Vol. 1 (6), pp. 529-539, 2001.

[11] P. C. H su, and Y. Guo, "Antioxidant nutrients and lead toxicity," Toxicol, Vol. 180, pp. 33-44, 2002.

[12] G. Flora, D. Gupta, and A. Tiwari, "Toxicity of lead: are view with recent up dates," Interdiscip. Toxicol, Vol. 5 (2), pp. 47 $58,2012$.

[13] O. Chalkiadaki, M. Dassenakis, N. Lydakis-Siùantiris, and M. Scoullos, "Tissue specific, time and dose dependence impact of Lead to a commercial marine Mediterranean organism", [Lesvos Island. Greece: $11^{\text {th }}$ Panhellenic Symposium on Oceanography and Fisheries, Mytilene, 2015].

[14] J. Thyrring, B. K. Juhl, M. Holmstrup, M. E. Blicher, and K. M. Sejr, "Does acute lead $(\mathrm{Pb})$ contamination influence membrane fatty acid composition and freeze tolerance in intertidal blue mussels inarctic Greenland?" Ecotoxicol, 2015, DOI: $10.1007 / \mathrm{s} 10646-015-1539-0$.

[15] Y. H. Cheung, and M. H. Wong, "Trace metal contents of the pacific oyster (Crassostrea gigas) purchased from market sin Hong Kong,” J. Environ. Manag, Vol. 16 (6), 753-761, 1992.

[16] O. H. Lowry, NJ. Rosebrough, A. L. Farr, and RJ. Randall," Protein measurement with the folin phenol reagent.),"J. Exp. Mar. Biol. Ecol, Vol. 12, pp. 103-118, 1951

[17] H. H. Draper, and M. Hadley, "Malondialdehyde determination as index of lipid 625 peroxidation, "Method.
Enzymol, Vol. 86, pp. 421-431, 1990.

[18] G. L. Ellman,"Tissue sulfhydryl groups," Arch. Biochem. Biophysics, Vol. 82, pp. 70-77, 1959.

[19] M. C. Jacques-Silva, C. W. Nogueira, and L. C. Broch,“ Diphenyldiselenide and ascorbic acid changes deposition of selenium and ascorbic acid in live rand brain of mice," Pharmacol. Toxicol, Vol. 88, pp. 119-125, 2001.

[20] C. Beauchamp, and I. Fridovich,"Superoxide dismutase: Improved assays and an assay applicable to acrylamide gels,"Anal. Biochem, Vol. 44, pp. 276-287, 1971.

[21] L. Flohe, and W. A. Gunzler, "Assays of gluthathione peroxidase," Method. Enzymol, Vol. 105, pp. 114-121, 1984

[22] H. Aebi, "Catalase in vitro," Method. Enzymol, Vol. 105, pp. $121-126,1984$

[23] A. Viarengo, E. Ponzano, F. Dondero, and R. Fabbri,“A simple spectrophotometric method for metallothionein evaluation in marine organisms: An application to Mediterranean and Antarctic molluscs," Mar. Environ. Res, Vol. 44, pp. 69-84, 1997.

[24] S. Petrovic, B. Ozretic, M. Krajnovic-Ozretic, and D. Bobinac," Lysosomal membrane stability and metallothioneins in digestive gland of mussels (Mytilus galloprovincialis Lam.) as biomarkers in a field study," Mar. Pollut. Bullet, Vol. 42, pp. 1373-1378, 2001.

[25] G. L. Ellman, K. D. Courtney, V. Abdres, and R. M. Featherstonem, Biochem. Pharmacol. Physiol. 3884-3890. 1961.

[26] R. Martoja, and M. Martoja-Pierson, Initiation aux techniques de l'histologie animale, Masson et Cieeds, Paris, 1967, pp. 1232 .

[27] B. Fernandez, J. A. Campillo, C. Martinez-Gómez, and J. Benedicto, "Antioxidant responses in gills of mussel (Mytilus galloprovincialis) as biomarkers of environmental stress along the Spanish Mediterranean coast, "Aquat. Toxicol, Vol. 99, pp. 186-197, 2010.

[28] A. Viarengo, L. Cansi, M. Pertica, G. Pou, M. N. Moore, and M. Omjneu, "Heavy metal effects on lipid peroxidation in the tissue of Mytilus galloprovincialis clam," Comp. Biochem. Physiol, Vol. 97 (C), pp. 37-42, 1990.

[29] H. Yin, L. Xu, and N. A. Porter," Free Radical Lipid Peroxidation. Mechanisms and Analysis," Chemrev, Vol. 111 (10), pp. 5944-5972, 2011.

[30] S. Gawel, M. Wardas, E. Niedworok, and P. Wardas," Malondialdehyde (MDA) as a lipid peroxidation marker,”Wiad. Lek, Vol. 57 (9-10), pp. 453-5, 2004.

[31] S. Bejaoui, K. Telahigue, I. Chetoui, I. Rabeh, C. Fouzai, W. Trabelsi, I. Houas-Gharsallah, M. ElCafsi, and N. Soudani, "Integrated Effect of Metal Accumulation, Oxidative Stress Responses and DNA Damage in Venerupis Decussata Gills Collected From Two Coast Tunisian Lagoons," J. E. C. E, Vol. 2, No. 2, pp. 44-51, 2018.

[32] S. García-Medina, M. Galar-Martínez, L. M. Gómez-Oliván, K. Ruiz-Lara, H. Islas-Flores, and E. Gasca-Péreza,"Relation ship between genotoxicity and oxidative stress induced by mercury on common carp (Cyprinus carpio) tissues," Aqua. Toxicol, Vol, 192, pp. 207-215, 2017. 
[33] A. A. Dayem, M. K. Hossain, S. B. Lee, K. Kim, S. K. Saha, G. M Yang, H. Y. Choi, and S. G. Cho," The Role of Reactive Oxygen Species (ROS) in the Biological Activities of Metallic Nanoparticles,’Int. J. Mol. Sci, Vol. 18 (1), pp. 120, 2017.

[34] G. Hariharan, R. Purvaja, and R. Ramesh, "Toxic Effects of lead on biochemical and histological alterations in green mussel (Pernaviridis) induced by environmentally relevant concentrations," J. Toxicol. Environ. Health, Vol, 77 (A), pp. 246-260, 2014.

[35] N. Sharma, N. K. Singh, O. P. Singh, V. P and Eyand P. K. Verma, "Oxidative Stress and Antioxidant Status during Transition Period in Dairy Cows," Asian-Aust. J. Anim. Sci, Vol. 24, No. 4, pp. 479-484, 2011.

[36] J. P. Coelho, M. Rosa, E. Pereira, A. Duarte, and M. A. Pardal, "Pattern and annual rates of Scrobicularia plana mercury bioaccumulation in a human induced mercury gradient (RiadeAveiro, Portugal)," Estuar. Coast. Shelf. Sci, Vol. 69, pp. 629-635, 2006.

[37] K. Chaudhary, S. Agarwal, and S. Khan, Role of Phytochelatins (PCs), Metallothioneins (MTs), and Heavy Metal ATPase (HMA) Genesin Heavy Metal Tolerance, Springer International Publishing AG, part of Springer Nature
Prasaded, Vol. 39R, Mycoremediation and Environmental Sustainabil, 2018.

[38] Y, Fang, H. Yangand B. Liu, "Tissue-specific response of metallothionein and superoxide dismutase in the clam Mactra veneriformis under sublethal mercury exposure,"Ecotoxicol, Vol. 21, pp. 1593-1602, 2012.

[39] L. Guilhermino, P. Barros, M. C. Silva, and A. M. V. M. Soares, "Should the use of inhibition of cholinesterase as a specific biomarker for organophosphate and carbamate pesticides be questioned?" Biomarkers, Vol. 3, pp. 157-163, 1998.

[40] S. Najimi, A. Bouhaimi, M. Daubèze, A., Zekhnini, J. Pellerin, and J. F. Narbonne, "Use of acetylcholinesterase in Perna perna and Mytilus galloprovincialis as a biomarker of pollution in Agadir Marine Bay (South of Morocco),"Bull. Environ. Contam. Toxicol, Vol. 58 (6), pp. 901-908, 1997.

[41] A. L. Dafre, I. D. Medeiros, I. C. Muller, E. C. Ventura, and A. C. D. Bainy, "Antioxidant enzymes and thiol/disulfide status in the digestive gland of the brown mussel Perna perna exposed to lead and paraquat," Chem. Biol. Interact, Vol. 149, pp. 97-105, 2004. 